\title{
STAT3 polymorphism and Helicobacter pylori CagA strains with higher number of EPIYA-C segments independently increase the risk of gastric cancer
}

\author{
Gifone A Rocha ${ }^{\dagger}$, Andreia MC Rocha, Adriana D Gomes, César LL Faria Jr, Fabrício F Melo, Sérgio A Batista, \\ Viviane C Fernandes, Nathálie BF Almeida, Kádima N Teixeira, Kátia S Brito and Dulciene Maria Magalhães Queiroz ${ }^{*+}$
}

\begin{abstract}
Background: Because to date there is no available study on STAT3 polymorphism and gastric cancer in Western populations and taking into account that Helicobacter pylori CagA EPIYA-C segment deregulates SHP-2/ERK-JAK STAT3 pathways, we evaluated whether the two variables are independently associated with gastric cancer.

Methods: We included 1048 subjects: H. pylori-positive patients with gastric carcinoma $(n=232)$ and with gastritis $(n=275)$ and 541 blood donors. Data were analyzed using logistic regression model.

Results: The rs744166 polymorphic $\mathrm{G}$ allele $(p=0.01 ; \mathrm{OR}=1.76 ; 95 \% \mathrm{Cl}=1.44-2.70)$, and CagA-positive (OR=12.80; $95 \% \mathrm{Cl}=5.58-19.86)$ status were independently associated with gastric cancer in comparison with blood donors. The rs744166 polymorphism ( $p=0.001 ; \mathrm{OR}=1.64 ; 95 \% \mathrm{Cl}=1.16-2.31)$ and infection with $\mathrm{H}$. pylori CagA-positive strains possessing higher number of EPIYA-C segments ( $p=0.001 ; \mathrm{OR}=2.28 ; 95 \% \mathrm{Cl}=1.41-3.68$ ) were independently associated with gastric cancer in comparison with gastritis. The association was stronger when host and bacterium genotypes were combined ( $p<0.001 ; \mathrm{OR}=3.01 ; 95 \% \mathrm{Cl}=2.29-3.98$ ). When stimulated with LPS (lipopolysaccharide) or Pam3Cys, peripheral mononuclear cells of healthy carriers of the rs744166 GG and AG genotypes expressed higher levels of STAT3 mRNA than those carrying AA genotype ( $p=0.04$ for both). The nuclear expression of phosphorylated p-STAT3 protein was significantly higher in the antral gastric tissue of carriers of rs744166 GG genotype than in carriers of $A G$ and $A A$ genotypes.
\end{abstract}

Conclusions: Our study provides evidence that STAT3 rs744166 G allele and infection with CagA-positive H. pylori with higher number of EPIYA-C segments are independent risk factors for gastric cancer. The odds ratio of having gastric cancer was greater when bacterium and host high risk genotypes were combined.

Keywords: Gastric cancer, STAT3 gene polymorphism, STAT3 rs744166, Helicobacter pylori, CagA, EPIYA-C segments

\section{Background}

Gastric cancer is the third leading cause of cancerrelated death in the world and one of the most common malignancies [1] especially in developing countries where the prevalence of Helicobacter pylori remains high.

\footnotetext{
* Correspondence: dqueiroz@medicina.ufmg.br

†Equal contributors

Laboratory of Research in Bacteriology, Faculdade de Medicina, Universidade Federal de Minas Gerais, Av. Alfredo Balena, 190 s/216, 30130-100 Belo Horizonte, Brazil
}

H. pylori infection leads to a persistent chronic gastric inflammation by inducing the expression of inflammatory cytokines that play an important role in the development of gastric cancer.

Polymorphisms in genes encoding pro-inflammatory cytokines have shown to increase the risk of gastric cancer, specifically interleukin- $1 \beta$ (IL1B-511/31, interleukin1 receptor antagonist $\left(I L 1 R N^{*} 2\right)$, and tumour necrosis factor A (TNFA-308) [2-6]. However, gastric cancer is a multifactorial disease and several genetic factors might be involved in the pathogenesis of the tumour.

\section{Ciomed Central}


There are evidences that signal transducer and activator of transcription protein 3 (STAT3) is implicated in the development and progression of cancer and plays a role in inducing neoplastic transformation. STAT3 participates in a series of tumourigenic processes including cell proliferation, cell survival, anti-apoptosis, angiogenesis, immune evasion and inflammation [7]. STAT3 is constitutively activated in several human cancers including skin, head and neck, ovarian, breast, colon, prostate and gastric cancer [8-14]. The mechanism of STAT3 activation relies on the stimulation by interleukin-6 (IL-6) cytokine family, in particular IL-6 and IL-11 and JAK (janus kinase)/STAT3-SHP (tyrosine phosphatase)-2/ERK (extracellular-signal-regulated kinases) $1 / 2$ signalling pathways emanating from the signal transducer glycoprotein (gp)130 $[15,16]$. SHP-2 is a feedback inhibitor of JAK/STAT3 signalling. Indeed, higher expression of SHP-2 by gain-of-function in mutant mouse results in reduced phosphorylation of STAT3 [17]. Otherwise, increased STAT3 secretion is observed in knock-in mice harbouring mutation abrogating SHP-2/ ERK1/2. Notably, these knock-in mice develop gastric tumour [18-20].

The SNP (single nucleotide polymorphism) rs744166 in the intron 2 of STAT3, located on chromosome $17 q 21$, has recently been associated with gastric cancer in a Chinese population [21], as well as colorectal cancer in American population of European origin [22] and non-small-cell lung cancer in a Chinese population [23]. Associations between other STAT3 polymorphisms and solid tumours have also been demonstrated [24, 25].

In addition to host factors, $H$. pylori virulent factors increase the risk of gastric cancer, notably the cytotoxinassociated antigen (CagA) encoded by the cagA gene (cytotoxin-associated gene A). Patients infected with CagApositive $H$. pylori strains either possessing EPIYA-D or higher number of EPIYA-C segments are at increased risk of gastric cancer [6,26-30]. CagA is injected into gastric epithelial cells, via bacterial type-IV secretion system, where it undergoes tyrosine phosphorylation at specific carboxi-terminal region comprising a variable number of EPIYA (Glu-Pro-Ile-Tyr-Ala) segments. Four distinct EPIYA segments designated EPIYA-A, B, C and D have been described according to different amino acids flanking each EPIYA motif. $H$. pylori strains circulating in Western countries possess EPIYA-A and EPIYA-B that are followed by 0-3 EPIYA-C segments, whereas $H$. pylori strains from East Asian countries possess EPIYA-A, EPIYA-B and EPIYA-D sites. Phosphorylated EPIYA-C or EPIYA-D motif acts as a specific binding site that interacts with $\mathrm{SH} 2$ domain-containing SHP-2 abnormally triggering the SHP-2/mitogen-activated protein kinases (MAPK)/ERK1/ 2-JAK/STAT3 pathways. It is worth mentioning that CagA possessing EPIYA-D or higher number of EPIYA-C segments binds more robustly to SHP-2 [31].
Taking these considerations together and the fact that to date there are no studies evaluating the STAT3 polymorphism and risk of gastric cancer in Western populations; we assessed the STAT3 polymorphism and CagA status as well as EPIYA-C pattern of $H$. pylori strains and risk of gastric cancer.

Therefore, the data were analyzed in logistic regression models in order to identify variables independently associated with increased risk of gastric cancer. We also evaluated whether the polymorphism might be functional by assessing the ability of peripheral blood mononuclear cells (PBMCs) from healthy volunteer carriers and non carriers of the polymorphic allele to express STAT3 mRNA. Finally, we evaluated the nuclear expression of phosphorylated (p)-STAT3 protein in the gastric mucosa of gastritis patients according to the STAT3 genotypes.

\section{Methods}

This study was approved by the Ethics Committees of Universidade Federal de Minas Gerais (UFMG ETIC 018/00) and Comissão Nacional de Ética (CONEP 096/ 02) and written informed consent was obtained from all subjects.

In total, 1048 subjects were included: $275 \mathrm{H}$. pyloripositive patients with chronic gastritis, $232 \mathrm{H}$. pyloripositive patients with distal gastric carcinoma and 541 voluntary healthy blood donors $(68.4 \% H$. pylori-positive). The patients were selected among those who underwent endoscopy for the evaluation of symptoms related to the upper gastrointestinal tract or underwent gastric surgery to remove gastric carcinoma at University Hospital/UFMG and Luxemburgo Hospital in Belo Horizonte, Brazil. The blood donors were from Fundação Hemominas, Minas Gerais, Brazil.

Most of the included individuals (>80 \%) were of low socioeconomic level with similar cultural habits and all were native of Minas Gerais state with the same ethnic background, approximately $33 \%$ of Portuguese, $33 \%$ of Amerindians and $33 \%$ of African ancestry, homogeneously present in each individual [32].

In the gastritis patients, endoscopic biopsy samples of the antral and oxyntic gastric mucosa were obtained for histological and microbiological studies (culture, urease test and PCR for $H$. pylori specific genes) to determine $H$. pylori status. Antral and oxyntic biopsy specimens were routinely processed and histological sections were stained with carbolfuchsin [6] for $H$. pylori investigation and hematoxyllin and eosin for histological evaluation according to the updated Sydney System [33]. Mononuclear $(\mathrm{MN})$ and polymorphonuclear (PMN) cell infiltrations were graded as absent (0), mild (1), moderate (2), or marked (3). In the gastric cancer patients, the fragments for the analyses of the presence of $H$. pylori were obtained from the stomach removed by gastrectomy within one 
hour of resection. The patients were also submitted to the ${ }^{13} \mathrm{C}$-urea breath test imediatly before endoscopy to determine $H$. pylori status. The patients were considered to be $H$. pylori positive when the culture was positive or when two among the other tests were positive.

\section{Amplification of the ureA and cagA genes}

All isolates were tested for the presence of specific $H$. pylori ureA gene [34]. The set of primers used and the reaction conditions are described in Table 1 . The standard Tx30a $H$. pylori strain was used as a positive control, and an Escherichia coli strain and distilled water were both used as negative controls.

In the patients, the cagA gene was amplified by means of two previously described primer pairs [35, 36]. A $H$. pylori strain from our collection (1010-95), known to be cagA-positive, was used as a positive control, and Tx30a $H$. pylori strain lacking cagA and distilled water were both used as negative controls. The primers used and the reaction conditions are described in Table 1 . The $H$. pylori strains were considered to be cagA-positive when at least one of the two reactions was positive.

\section{Amplification of the cagA EPIYA region}

For the PCR amplification of the 3' variable region of the cagA gene that contains the EPIYA sequences, 20 to $100 \mathrm{ng}$ of DNA were added to $1 \%$ Taq DNA polymerase buffer solution ( $\mathrm{KCl} 50 \mathrm{mM}$ and Tris- $\mathrm{HCl} 10 \mathrm{mM}$ ), $1.5 \mathrm{mM} \mathrm{MgCl}_{2}, 100 \mu \mathrm{M}$ of each deoxynucleotide, $1.0 \mathrm{U}$ Platinum Taq DNA polymerase (Invitrogen, São Paulo, Brazil), and 10 pmol of each primer, for a total solution volume of $20 \mu \mathrm{L}$. The primers used were previously described by Yamaoka et al. [37] and are listed in Table 1. The amplified products were electrophoresed in $1.5 \%$ agarose gel that was stained with ethidium bromide, and analyzed in an ultraviolet light transilluminator. The reaction yielded products of 500 to $850 \mathrm{bp}$ according to the number of EPIYA-C segments.

To confirm the results, the 3' variable region of the cagA gene was sequenced. Briefly PCR products were purified with the Wizard SV Gel and PCR Clean-Up System (Promega, Madison, MI) according to the manufacturer's recommendations. Purified products were sequenced using a BigDye ${ }^{\ominus}$ Terminator v3.1 Cycle Sequencing Kit in an ABI 3130 Genetic Analyzer (Applied Biosystems, Foster City, CA). The sequences obtained were aligned using the CAP3 Sequence Assembly Program (available from: http://pbil.univ-lyon1.fr/cap3.php). After alignment, nucleotide sequences were transformed into amino acid sequences using the Blastx program (available from: http://blast.ncbi.nlm.nih.gov/Blast.cgi) and compared to sequences deposited into the GenBank (http:// www.ncbi.nlm.nih.gov/Genbank/).

\section{H. pylori and CagA Status in the blood donors}

In the blood donors, $H$. pylori status was investigated by using a commercial ELISA kit (Cobas Core anti-H. pylori, EIA Roche, Basel, Switzerland), which was previously validated for the Brazilian population being $95.4 \%$ sensitive and $100 \%$ specific [38]. CagA status was investigated by serology using a commercial ELISA kit (Helicobacter pylori p120 CagA; Viva Diagnostika, Hürth, Germany), which was also previously validated for the Brazilian population being $97.4 \%$ sensitive and $88.9 \%$ specific [39].

\section{STAT3 SNP rs744166 polymorphism}

The STAT3 single nucleotide polymorphism (SNP) rs744166 was chosen to be investigated because in genome wide studies the $G$ allele was shown to be a protector factor for inflammatory bowel disease [26], which

Table 1 Primer pairs and conditions used in the PCR to detect H. pylori genes (ureA, cagA and 3' variable region of the cagA gene that contains EPIYA sequences) and in qRT-PCR to genotype STAT3 rs744166 and to evaluate STAT3 mRNA expression

\begin{tabular}{|c|c|c|c|c|}
\hline Gene & Primers $\left(5^{\prime}-3^{\prime}\right)$ & PCR conditions & $\begin{array}{l}\text { PCR } \\
\text { Product } \\
\text { (bp) }\end{array}$ & Reference \\
\hline \multirow[t]{2}{*}{ ureA } & F: GCCAATGGTAAATTAGTT & \multirow{2}{*}{$\begin{array}{l}95^{\circ} \mathrm{C}-5 \text { min.; } 34 \text { cycles }\left(94^{\circ} \mathrm{C} 1 \text { min., } 45^{\circ} \mathrm{C}-1 \text { min. and }\right. \\
72{ }^{\circ} \mathrm{C}-1 \text { min.) and } 72{ }^{\circ} \mathrm{C}-5 \text { min. }\end{array}$} & \multirow[t]{2}{*}{411} & \multirow[t]{2}{*}{34} \\
\hline & R: CTCCTTAATTGTTITTAC & & & \\
\hline \multirow[t]{2}{*}{$\operatorname{cag} A$} & F:CTGCAAAAGATTGTTTGCGAGA & \multirow{2}{*}{$\begin{array}{l}95^{\circ} \mathrm{C}-5 \mathrm{~min}, 34 \text { cycles }\left(95^{\circ} \mathrm{C} 1 \mathrm{~min}, 50^{\circ} \mathrm{C}-1 \mathrm{~min} \text { and }\right. \\
\left.72^{\circ} \mathrm{C}-1 \mathrm{~min}\right) \text { and } 72^{\circ} \mathrm{C}-15 \mathrm{~min}\end{array}$} & \multirow[t]{2}{*}{400} & \multirow[t]{2}{*}{35} \\
\hline & R:AGACGGTTTGTTAGAAAACGTC & & & \\
\hline \multirow[t]{2}{*}{$\operatorname{cag} A$} & F:GATAACAGGCAAGCTITTGAGG & \multirow{2}{*}{$\begin{array}{l}95^{\circ} \mathrm{C}-5 \mathrm{~min}, 38 \text { cycles }\left(94{ }^{\circ} \mathrm{C} 1 \mathrm{~min}, 55^{\circ} \mathrm{C}-1 \mathrm{~min} \text { and }\right. \\
\left.72{ }^{\circ} \mathrm{C}-2 \mathrm{~min} .\right) \text { and } 72^{\circ} \mathrm{C}-7 \mathrm{~min} .\end{array}$} & \multirow[t]{2}{*}{349} & \multirow[t]{2}{*}{36} \\
\hline & R:CTGCAAAAGATTGTTTGCGAGA & & & \\
\hline \multirow{2}{*}{$\begin{array}{l}\text { cagA } 3^{\prime} \\
\text { variable region }\end{array}$} & F: ACCCTAGTCGGTAATGGGTTA & \multirow{2}{*}{$\begin{array}{l}95^{\circ} \mathrm{C}-5 \mathrm{~min}, 35 \mathrm{cycles}\left(95^{\circ} \mathrm{C} 1 \mathrm{~min}, 50^{\circ} \mathrm{C}-1 \mathrm{~min} \text { and }\right. \\
72^{\circ} \mathrm{C}-1 \text { min.) and } 72{ }^{\circ} \mathrm{C}-7 \mathrm{~min}\end{array}$} & \multirow[t]{2}{*}{$500-850$} & \multirow[t]{2}{*}{37} \\
\hline & R: GTAATTGTCTAGTTTCGC & & & \\
\hline $\begin{array}{l}\text { STAT3 }^{\mathrm{a}} \\
\text { Rs } 744166\end{array}$ & $\begin{array}{l}\text { CTGTTTGTTCTATAAATTACTGTCA[A/ } \\
\text { G]GCTCGATTCCCTCAAGACATTACAG }\end{array}$ & $\begin{array}{l}60^{\circ} \mathrm{C}-1 \text { min., } 95^{\circ} \mathrm{C}-10 \text { min., } 50 \text { cycles }\left(95^{\circ} \mathrm{C}-15 \mathrm{s.},\right. \\
\left.50^{\circ} \mathrm{C}-90 \mathrm{~s} .\right) \text { and } 60{ }^{\circ} \mathrm{C}-1 \mathrm{~min} .\end{array}$ & 70 & \\
\hline
\end{tabular}

Bp, base pairs; ${ }^{a}$, Applied Biosystem, HS00374280-m1 
might be attributed to a higher production of STAT3, well known as protector of intestinal mucosa, but associated with gastric cancer in animal models [18-20].

The SNP rs744166 in the intron 2 of STAT3, located on chromosome 17q21, was analyzed in DNA extracted from leukocytes with the QIAamp DNA mini kit (QIAgen) by pre-designed Taqman SNP genotyping assay on ABI7500 real time PCR system (Applied Biosystems, Foster City, CA). The primer used and the reaction conditions are described in Table 1.

\section{in vitro stimulation of STAT3}

In order to evaluate the effect of the STAT3 rs744166 different genotypes on the mRNA expression, we used PBMCs from nine healthy subjects (three AA, three AG and three GG) of the laboratory team who were $H$. pylori negative, as determined by ${ }^{13} \mathrm{C}$-urea breath test. Blood samples were obtained from each subject after 8-h fast in five different days and were independently assayed. PBMCs were freshly isolated using Ficoll-Paque Plus (Amersham Biosciences, GE Healthcare, São Paulo, Brazil) and $9 \times 10^{5}$ cells were seeded in triplicate in 24 well plates containing RPMI 1640 supplemented with $10 \%$ fetal bovine serum, $100 \mathrm{U} / \mathrm{mL}$ penicillin and $100 \mu \mathrm{g} / \mathrm{mL}$ streptomycin in $5 \% \mathrm{CO}_{2}, 95 \%$ humidity at $37{ }^{\circ} \mathrm{C}$ for $24 \mathrm{~h}$. Thereafter, PBMCs were stimulated with LPS, an agonist of toll-like-receptor-4 (TLR-4), $100 \mathrm{ng} /$ $\mathrm{mL}$ from Escherichia coli 055:B5 (Sigma, St Louis, MO) or Pam3Cys, an agonist of TLR-2, $100 \mathrm{ng} / \mathrm{mL}$ (EMC Microcollections $\mathrm{GmbH}$, Tuebingen, Germany) both diluted in $500 \mu \mathrm{L}$ RPMI 1640 and incubated in $5 \% \mathrm{CO}_{2}$, $95 \%$ humidity at $37{ }^{\circ} \mathrm{C}$ for $6 \mathrm{~h}$. Unstimulated cells were used as a negative control. According to an initial protocol time course experiment, six hours proved to be an ideal time point to detect STAT3 expression after stimulation with both LPS and Pam3Cys.

\section{STAT3 RNA extraction}

Total RNA was purified by using RNeasy Mini Kit (QIAgen). The extracted RNA was then treated with RQ1 RNase-free DNase (Promega, São Paulo, Brazil). The RNA concentration was determined by spectrophotometry using NanoDrop 2000 (Thermo Scientific, Wilmington, NC). One hundred nanograms of RNA were reverse transcribed to cDNA using a High Capacity cDNA (Applied Biosystem). A cDNA synthesis reaction including all components except the reverse transcriptase was subsequntly used as control for quantitative real time PCR (qRT-PCR).

\section{Relative quantification of the STAT3 transcripts}

The STAT3 calibrator was purified cDNA isolated from PBMCs containing STAT3 sequence. The remaining calibrators were made by a serial two-fold dilution ( $20.0 \mathrm{ng} /$ $\mu \mathrm{L}-1,280.0 \mathrm{ng} / \mu \mathrm{L}$ ) and tested in triplicate to determine the most effective PCR amplification conditions. The calibration curve produced $\mathrm{r}^{2}$ value of 0.99 . The STAT3 mRNA expression was analyzed by using Taqman primers and probe (Applied Biosystems). The qRT-PCR was performed with thermal cycling conditions of $50{ }^{\circ} \mathrm{C}$ $2 \mathrm{~min}, 95^{\circ} \mathrm{C}-10 \mathrm{~min}, 50$ cycles of $95{ }^{\circ} \mathrm{C}-15 \mathrm{~s}$ and, $60{ }^{\circ} \mathrm{C}-$ $1.5 \mathrm{~min}$. Distilled water was also used as a negative control.

Relative quantification of the STAT3 transcripts was determined by means of algebraic calculation using the method $2^{-\Delta \Delta \mathrm{Ct}}[40]$, normalized to the glyceraldheyde 3phosphate dehydrogenase.

\section{Immunohistochemistry}

Because it is known that expression of STAT3 in tumour tissue depends on the stage of the tumour $[41,42]$, the p-STAT3 nuclear expression was assessed in formalin-fixed paraffin-embedded sections of the antral and corpus mucosa of gastritis patients harbouring rs744166 AA, AG and GG genotypes, eight in each group, who were randomly selected, by conventional immunohistochemistry. To retrieve antigenicity, the sections were placed in $10 \mathrm{mmol} / \mathrm{L}$ citrate buffer solution, $\mathrm{pH}$ 6.0, and heated in a microwave for $12 \mathrm{~min}$. Samples were then treated with $3 \%$ hydrogen peroxide-metanol for 12 min to block endogenous peroxidase and, rinsed with distilled water. The assay was performed using as primary antibody 1:50 diluted rabbit anti-human phospho-STAT3 (pTyr-705) IgG (Sigma, Cambridge, UK) with modifications including incubation with Novocastra Post Primary Block for $30 \mathrm{~min}$ and with NovoLink polymer for $30 \mathrm{~min}$ (Novocastra Laboratories Ltd, São Paulo, Brazil). Sections were counterstained with Meyer's hematoxycillin and then mounted. Negative controls were carried out by omission of the primary antibody. Known immunostaining positive slides were used as positive controls. The gastric epithelial cells with the nucleus stained in brown were considered positive for p-STAT3. The number of p-STAT3-positive cells (proportional to the number of all cells) was evaluated in 20 representative visual fields at a magnification of 400X in an Olympus CX41RF microscope. Slides were examined by two independent observers who were blinded to the other results. The percentage of positive cells for p-STAT3 was classified as 0 (none), 1 ( $\leq 50 \%), 2$ (50 to $90 \%$ ), and $3(>90 \%)$ and staining intensity was graded in three step scale, as follows: 1 (low), 2 (medium) and 3 (high) intensity.

\section{Statistical analysis}

The associations of the STAT3 genotypes with the number of EPIYA-C segments and gender were evaluated by the $\chi^{2}$ 
test with Yates' correction and the mean age by the Student's $t$ test or ANOVA and scores by the Kruskal-Wallis test. Regarding to STAT3 mRNA expression, scores of nuclear p-STAT3 in the gastric cells and the degree of gastric inflammation, the differences between the groups were evaluated by the two-tailed Mann-Whitney $U$-test. $p$ values $\leq 0.05$ were considered as significant. The associations of the variables including the rs744166 STAT3 genotypes (treated as variables having 3 values with 0 meaning the AA genotype, 1 the carrier of one $G$ allele and 2 the GG genotype), CagA status, CagA EPIYA-C patterns, age and gender were investigated in logistic regression models by comparing gastric cancer patients with blood donors or gastritis patients (dependent variable). Association between the polymorphism and $H$. pylori status was also evaluated in a logistic regression model in the group of blood donors. Finally, in other model, we investigated whether the combined score of the number of EPIYA-C segments and STAT3 polymorphism increased the risk for gastric cancer. All variables with $\mathrm{p}$ values $\leq 0.25$ were included in the multivariate analysis. Odds ratio (OR) and $95 \%$ confidence interval $(\mathrm{CI})$ were used as an estimate of the risk. The Hosmer-Lemeshow goodness-of-fit test was used to evaluate the fit of the model [43].

Data were analyzed with SPSS, version 17 (SPSS Inc., Chicago, IL).

\section{Results}

\section{Demographic data and rs744166 STAT3 polymorphism}

The characteristics of the population are listed in Tables 2 and 3.

In the blood donors (Table 2), H. pylori infection was more frequently observed in males than in females $(p=$ 0.02 ; $\mathrm{OR}=1.65 ; 95 \% \mathrm{CI}=1.08-2.54$ ), but, when the data were adjusted for the socio-economical level, the association disappeared $(p<0.001 ; \mathrm{OR}=0.53 ; 95 \% \mathrm{CI}=0.40-$
0.70 for socio-economical level and $\mathrm{p}=0.12$ for gender). The CagA positivity ( $p=0.93$; OR $=0.99 ; 95 \% \mathrm{CI}=0.58-$ $1.68)$ and the mean age $(p=0.85)$ did not differ when males and females were compared (Table 2). Also, the frequency of STAT3 AA, AG and GG genotypes did not differ between males and females $\left(\chi^{2}=1.38,2\right.$ degrees of freedom, $p=0.50$ ) and between $H$. pylori-positive and -negative status $\left(\chi^{2}=0.73,2\right.$ degrees of freedom, $\left.p=0.69\right)$.

In the group of gastritis, the distribution of STAT3 genotypes was not different in respect to the gender $\left(\chi^{2}=3.05\right.$, 2 degrees of freedom $p=0.22)$ and cagA status $\left(\chi^{2}=3.91\right.$, 2 degrees of freedom, $\mathrm{p}=0.14$ ), but a tendency of association was observed between the distribution of EPIYA-C segments and STAT3 genotypes $\left(\chi^{2}=4.73,2\right.$ degrees of freedom, $\mathrm{p}=0.09$ ), the infection by strains with EPIYA-CC or EPIYA-CCC being less frequent in the GG genotype carriers (Table 3). In respect to the EPIYA pattern, neither difference in the mean age $(p=0.65)$ nor in the gender $\left(\chi^{2}=0.25\right.$, 2 degrees of freedom, $p=0.88$ ) was observed (Table 4).

In the gastric cancer patients, there was no significant difference in the distribution of the STAT3 genotypes and the number of EPIYA-C segments $(p=0.16$; Kruskal Wallis test) and cagA status $\left(\chi^{2}=2.73,2\right.$ degrees of freedom, $p=0.26$ ) (Table 3). The gender neither associated with the STAT3 genotypes $\left(\chi^{2}=1.03,2\right.$ degrees of freedom $p=0.60)$ nor with the number of EPIYA-C segments $\left(\chi^{2}=0.03,2\right.$ degrees of freedom, $p=0.98$ ), (Table 4). Infection by strains with higher number of EPIYA-C segments increased with increasing age $(p=0.004)$.

\section{Comparisons between the groups}

No significant difference was observed between the group of gastritis patients and blood donors regarding to the STAT3 genotype distribution $(p=0.75$; OR $=1.05 ; 95 \%$ $\mathrm{CI}=0.76-1.45)$ and CagA status $(p=0.22$; OR $=1.19 ; 95 \%$ $\mathrm{CI}=0.76-1.45)$.

Table 2 Distribution of the STAT3 rs744166 genotypes according to the gender, mean age, H. pylori status and CagA status in blood donors $(n=541)$

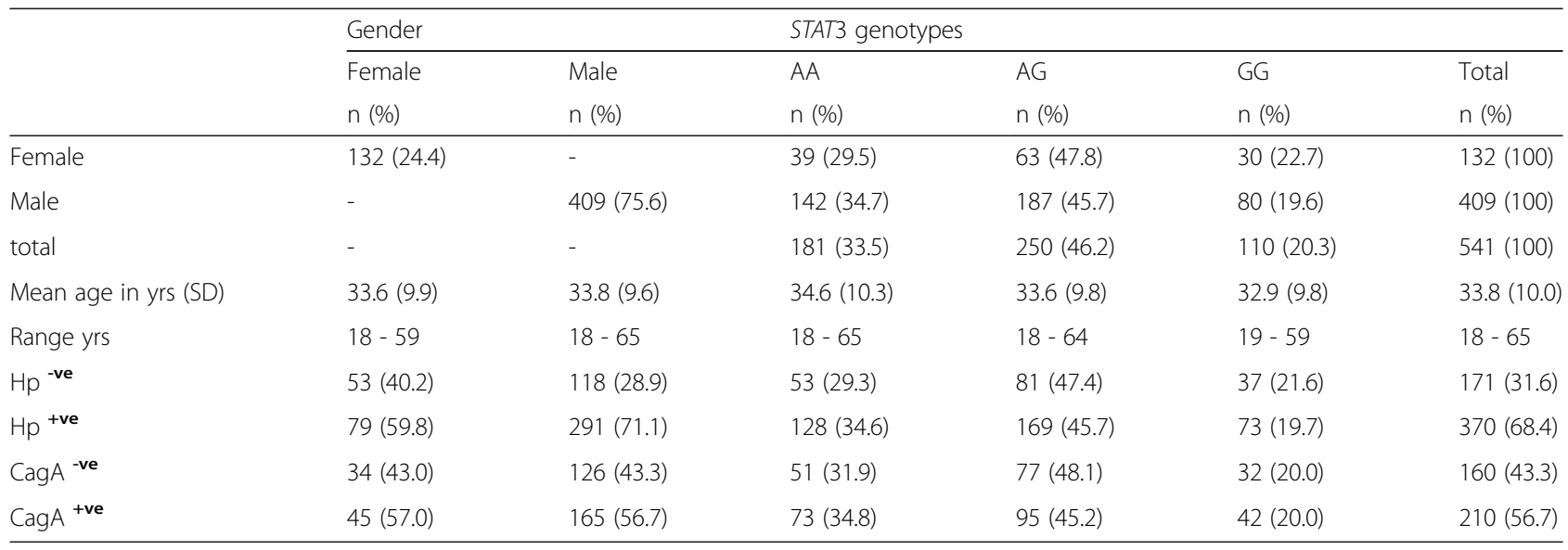

n, number; SD, standard deviation; yrs, years; $\mathrm{Hp}$, Helicobacter pylori; ${ }^{-\mathrm{ve}}$, negative; $^{+\mathrm{ve}}$, positive 
Table 3 Distribution of the STAT3 rs744166 genotypes according to the gender, mean age, CagA status and EPIYA-C patterns in patients with gastritis and gastric cancer

\begin{tabular}{|c|c|c|c|c|}
\hline \multirow[t]{3}{*}{ Disease } & \multicolumn{4}{|c|}{ STAT3 genotypes } \\
\hline & $\mathrm{AA}$ & $A G$ & GG & Total \\
\hline & $\mathrm{n}(\%)$ & n (\%) & n (\%) & n (\%) \\
\hline \multicolumn{5}{|l|}{ Gastritis $(n=275)$} \\
\hline Female & $61(33.7)$ & $78(43.1)$ & $42(23.2)$ & $181(65.8)$ \\
\hline Male & $27(28.7)$ & 36 (38.3) & $31(33.0)$ & $94(34.2)$ \\
\hline Mean age in yrs (SD) & $49.6(17.1)$ & $53.9(18.6)$ & $58.6(15.3)$ & $53.8(17.6)$ \\
\hline $\operatorname{cag} A^{-v e}$ & $26(25.7)$ & $49(48.5)$ & $26(25.7)$ & $101(36.7)$ \\
\hline $\operatorname{cag} \mathrm{A}^{+\mathrm{ve}}$ & $62(35.6)$ & $65(37.4)$ & $47(27.0)$ & $174(62.3)$ \\
\hline EPIYA-AB & $1(25.5)$ & $1(25.5)$ & $2(50.0)$ & $4(2.3)$ \\
\hline EPIYA-ABC & $44(32.1)$ & $53(38.7)$ & $40(29.2)$ & 137 (78.7) \\
\hline EPIYA-ABCC & 15 (53.6) & $8(28.6)$ & $5(17.8)$ & $28(16.1)$ \\
\hline EPIYA-ABCCC & $2(40.0)$ & $3(60.0)$ & 0 & $5(2.9)$ \\
\hline \multicolumn{5}{|l|}{ Gastric cancer $(n=232)$} \\
\hline Female & 19 (21.8) & $41(47.1)$ & $27(31.0)$ & $87(37.5)$ \\
\hline Male & $40(27.6)$ & $61(42.1)$ & $44(30.3)$ & $145(62.5)$ \\
\hline Mean age in yrs (SD) & $63.4(13.3)$ & $61.5(12.9)$ & $61.7(13.6)$ & $62.0(13.2)$ \\
\hline $\operatorname{cag} A^{-v e}$ & $2(10.5)$ & $11(57.9)$ & $6(31.6)$ & $19(8.2)$ \\
\hline $\operatorname{cag} \mathrm{A}^{+\mathbf{v e}}$ & $57(26.8)$ & $91(42.7)$ & $65(30.5)$ & $213(91.8)$ \\
\hline EPIYA- AB & 0 & $2(66.7)$ & $1(33.3)$ & $3(1.4)$ \\
\hline EPIYA-ABC & $28(23.1)$ & $53(43.8)$ & $40(33.1)$ & $121(56.8)$ \\
\hline EPIYA-ABCC & $22(30.1)$ & $30(41.1)$ & $21(28.8)$ & $73(34.3)$ \\
\hline EPIYA-ABCCC & $7(43.8)$ & $6(37.5)$ & $3(18.7)$ & $16(7.5)$ \\
\hline
\end{tabular}

$\mathrm{n}$, number; SD, standard deviation; yrs, years. ${ }^{-v e}$, negative; ${ }^{+v e}$, positive

Table 4 Distribution of the EPIYA-C patterns according to the gender and mean age, in patients with gastritis and gastric cancer

\begin{tabular}{lllll}
\hline Disease & \multicolumn{3}{l}{ EPIYA pattern } \\
\cline { 2 - 5 } & $\mathrm{AB}$ & $\mathrm{ABC}$ & $\mathrm{ABCC}$ & $\mathrm{ABCCC}$ \\
\cline { 2 - 5 } & $\mathrm{n}(\%)$ & $\mathrm{n}(\%)$ & $\mathrm{n}(\%)$ & $\mathrm{n}(\%)$ \\
\hline Gastritis $(n=275)$ & $2(1.7)$ & $93(80.2)$ & $18(18.1)$ & $3(2.6)$ \\
Female & $2(3.4)$ & $44(75.9)$ & $10(19.5)$ & $2(3.5)$ \\
Male & $44.3(25.0)$ & $54.7(16.9)$ & $50.6(15.1)$ & $52.0(11.0)$ \\
Mean age in yrs (SD) & $27-73$ & $18-86$ & $27-73$ & $39-63$ \\
Range & & & & \\
Cancer ( $n=232)$ & $1(1.2)$ & $47(56.7)$ & $29(42.1)$ & $6(7.2)$ \\
Female & $2(1.5)$ & $74(56.9)$ & $44(41.6)$ & $10(7.7)$ \\
Male & $56.5(3.5)$ & $60.2(14.4)$ & $64.4(13.2)$ & $70.0(9.7)$ \\
Mean age in yrs (SD) & $54-59$ & $28-89$ & $33-92$ & $55-85$ \\
Range & &
\end{tabular}

n, number; SD, standard deviation; yrs, years
By comparing the blood donors with the patients with gastric cancer (Table 2 and Table 3), a significant difference was observed in the frequency of CagA positive status $(p<0.001 ; \mathrm{OR}=8.54 ; 95 \% \mathrm{CI}=4.99-14.76)$ and in the distribution of the STAT3 genotypes $\left(\chi^{2}=10.86,2\right.$ degrees of freedom, $p=0.004)$. By stratifying the gender, in respect to the STAT3 genotypes, the association remained for male gender $\left(\chi^{2}=7.54,2\right.$ degrees of freedom $\left.\mathrm{p}=0.02\right)$, but not for female gender $\left(\chi^{2}=2.57,2\right.$ degrees of freedom, $\left.p=0.28\right)$.

When the gastritis patients were compared with the gastric cancer patients, in the carriers of the rs744166 AA genotype, the frequency of infection with CagA strains with one EPIYA-C segment was significantly higher in the former $(p=0.01$; OR $=2.68 ; 95 \% \mathrm{CI}=$ 1.17 - 6.28). Otherwise, in the carriers of AG $(p=$ 0.002 ; $\mathrm{OR}=3.27 ; 95 \% \mathrm{CI}=1.42-7.67)$ or $\mathrm{GG}(p=0.01$; $\mathrm{OR}=4.2 ; 95 \% \mathrm{CI}=1.32-14.20$ ) genotypes, infection with strains with two or three EPIYA-C segments were more frequently observed in the gastric cancer than in the gastritis patients $(\mathrm{AB}$ was not included in the analysis and $\mathrm{ABCC}$ and $\mathrm{ABCCC}$ segments were analysed together in all analyses) (Table 3).

Infection by strains with higher numbers of EPIYA-C segments was more frequently observed in the gastric cancer than in the gastritis patients: females $(p<0.001$; $\mathrm{OR}=3.49 ; 95 \% \mathrm{CI}=1.75-6.97)$ and males $(p=0.007$; OR 2.68; $95 \%$ CI $=1.23$ - 5.93) (Table 4).

The number of EPIYA-C segments was positively associated with the mean age of the patients with gastric cancer $(p=0.004)$, but not with the gender $(p=0.99)$ (Table 4). In the group with gastritis, the number of EPIYA-C segments neither associated with mean age nor with gender $(p>0.64)$ (Table 4$)$.

\section{Association between STAT3 rs744166 genotypes and gastric cancer}

The alleles were in Hardy-Weinberg equilibrium in the controls $(\mathrm{p}=0.19)$.

In the blood donors, a logistic regression demonstrated that the STAT3 genotypes were not associated with $H$. pylori infection, even including the age and gender in the model $(p=0.66$; OR $=0.94 ; 95 \% \mathrm{CI}=0.73-1.22)$.

Compared with blood donors, the rs744166 polymorphic G allele, CagA-positive status, age and gender were independently associated with gastric cancer (Table 5).

Next, we compared gastric carcinoma patients with those with gastritis in order to evaluate the number of EPIYA-C segments as a predictor of gastric cancer as well as the co-participation of the bacterial EPIYA-C segments and STAT3 polymorphism in the risk of the disease. The logistic regression analysis showed that the rs744166 polymorphism and higher number of EPIYA-C segments were independently associated with gastric 
Table 5 Host and bacterium variables associated with gastric cancer $(n=232)$ in comparison with $H$. pylori-positive blood donors $(n=370)$

\begin{tabular}{|c|c|c|c|c|}
\hline \multirow[t]{2}{*}{ Covariate } & \multirow{2}{*}{$\begin{array}{l}\text { Univariate analysis } \\
p\end{array}$} & \multicolumn{3}{|c|}{ Multivariate analysis } \\
\hline & & OR & $95 \% \mathrm{Cl}$ & $p$ \\
\hline Age & $<0.001$ & 1.20 & $1.16-1.23$ & $<0.00$ \\
\hline Gender & $<0.001$ & 2.99 & $1.48-6$ & 0.002 \\
\hline rs744166 & 0.002 & 1.76 & $1.14-2.70$ & 0.01 \\
\hline $\operatorname{Cag} \mathrm{A}^{+\mathrm{ve}}$ & $<0.001$ & 12.80 & $5.48-29.86$ & $<0.00$ \\
\hline
\end{tabular}

The Hosmer-Lemeshow test showed good fit (10 steps; 8 degrees of freedom; $p=0.20$ ). rs 744166 genotype was treated as categorical variables having 3 values with 0 meaning the AA genotype, 1 the carrier of one $G$ allele and 2 the GG genotype, ${ }^{+v e}$, positive

cancer (Table 6). Harbouring STAT3 polymorphism plus infection with CagA strains possessing higher number of EPIYA-C segments was more strongly associated with gastric cancer (Table 6).

\section{STAT3 rs744166 polymorphism and microscopic aspects of the gastric mucosa}

Results of previous studies have shown that infection with $H$. pylori CagA-positive strains are associated with more prominent gastric inflammation and infection with CagA strains possessing higher number of EPIYA-C segments are associated with pre-malignant gastric lesions. Thus to avoid interference of those variables, in the group of patients with gastritis infected with CagAnegative strains we analyzed the association between STAT3 and gastritis by treating rs744166 genotypes as dichotomous variables: $\mathrm{AA}=0$ and $\mathrm{AG}+\mathrm{GG}=1$. The presence of $\mathrm{G}$ allele was associated with higher degree of mononuclear cells in the corpus mucosa (median $=1$, range, $0-1$ vs. median $=2$, range, $1-3 ; p=0.01$ ).

\section{Association between rs744166 polymorphism and in vitro expression of STAT3}

When stimulated with LPS or Pam3Cys, PBMCs of the healthy carriers of the GG genotype expressed significantly higher amounts of STAT3 mRNA than carriers of the AG or AA genotype (Fig. 1).

\section{Expression of p-STAT3 protein according to the STAT3 genotypes}

Figure 2 shows nuclear localization of p-STAT3 in the antral glandular cells and stroma cells of carriers of AA and GG STAT3 rs744166 genotypes. The percentage of p-STAT3 expression was significantly higher in the nuclei of the antral glandular cells $(p=0.005$ and $p=0.003)$ and in the gastric stroma cells $(p=0.01$ and $p=0.007)$ of the patients carrying the rs744166 GG genotype than in those carrying AG or AA genotype, respectively, but no differences were observed between the genotypes AA and AG $(p \geq 0.49)$ (Fig. 3).

\section{Discussion}

To the best of our knowledge, this is the first study to demonstrate that STAT3 rs744166 G allele is associated with increased risk of gastric cancer in a Western population. Conversely, the results of the study in a Chinese population [21] showed that $G$ allele was associated with a decreased risk of gastric cancer, which may be explained by differences in the role of host polymorphisms and risk of gastric cancer between Western and Eastern populations including polymorphism in genes coding IL $1 B-511$ and IL1RN*2 [1-6, 44].

There are growing evidences suggesting that STAT3 has a crucial role in carcinogenesis. STAT3 regulates expression of several genes involved in a variety of cellular responses including proliferation, differentiation, apoptosis

Table 6 Host and bacterium variables associated with gastric cancer $(n=213)$ in comparison with gastritis $(n=174)$ in patients infected by H. pylori cagA-positive strains

\begin{tabular}{|c|c|c|c|c|}
\hline \multirow[t]{2}{*}{ Covariates } & \multirow{2}{*}{$\frac{\text { Univariate analysis }}{p}$} & \multicolumn{3}{|c|}{ Multivariate analysis } \\
\hline & & OR & $95 \% \mathrm{Cl}$ & $p$ \\
\hline \multicolumn{5}{|l|}{ First model $^{a}$} \\
\hline Age & $<0.001$ & 1.04 & $1.02-1.05$ & $<0.001$ \\
\hline Gender & $<0.001$ & 3.58 & $2.10-6.09$ & $<0.001$ \\
\hline rs744166 & 0.007 & 1.64 & $1.16-2.31$ & 0.005 \\
\hline EPIYA-C number & $<0.001$ & 2.28 & $1.41-3.68$ & 0.001 \\
\hline \multicolumn{5}{|l|}{ Second model ${ }^{b}$} \\
\hline Age & $<0.001$ & 1.05 & $1.05-1.06$ & $<0.001$ \\
\hline Gender & $<0.001$ & 3.23 & $2.02-5.17$ & $<0.001$ \\
\hline rs744166 plus EPIYA-C number & $<0.001$ & 3.01 & $2.29-3.97$ & $<0.001$ \\
\hline
\end{tabular}

The Hosmer-Lemeshow tests showed good fit for models ${ }^{\mathrm{a}}(10 \mathrm{steps}, 8 \text { degrees of freedom; } p=0.42)^{\mathrm{b}}(10$ steps, 8 degrees of freedom; $p=0.25)$, OR, odds ratio; $95 \%$ $\mathrm{Cl}$ : confidence interval. We constructed two models studying the loci, according to the amount of $\mathrm{G}$ rs 744166 allele, treated as categorical variables having 3 values with 0 meaning the AA genotype, 1 the carrier of one G allele and 2 the GG genotype. In the second model the variable was obtained by the sum of the amount of STAT3 G allele and the number of EPIYA-C segments 


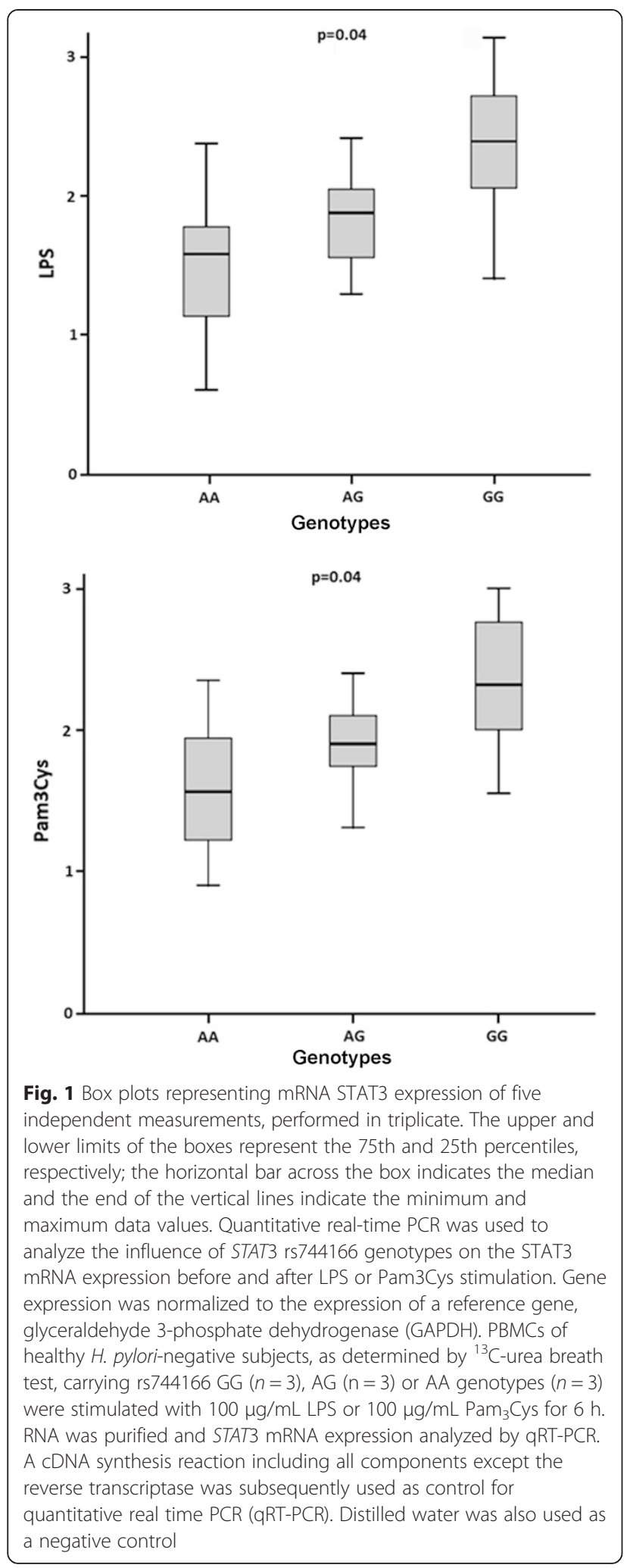

and wound healing [45]. STAT3 activity supports tumourcell survival by up regulating expression of the antiapoptotic protein $\mathrm{BCL}-\mathrm{X}_{\mathrm{L}}$ (B-cell lymphoma-2-like) and many other proteins involved in cell proliferation and survival including myeloid cell leukaemia 1 (MCL1), cyclin D1 and MYCC [14, 46]. Furthermore, STAT3 selectively induces and maintains a pro-inflammatory microenvironment that further supports tumour progression.

The results of the present study are in opposite to that observed in patients with Crohn's disease who are more frequently carriers of the A than the G allele [26]. There are evidences that physiologic consequences of the multiple STAT3 actions depend on the specific cell types involved [45]. STAT3 plays a protective role in the intestinal mucosa as demonstrated in knockout mice with intestinal epithelial cell-specific deletion of STAT3 that exhibit more severe induced acute colitis than the control group with a functioning STAT3 $[19,47]$. It has been suggested that increased STAT3 signalling may predispose to up regulation of trefoil factor family3 (TFF3) gene expression in intestinal globet cells and protection against IBD [19] and downregulates trefoil factor family-1 (TFF1), a gastric-specific tumour suppressor, predisposing to neoplastic transformation [48]. In fact, mice with knock-in mutation located at Y757F on gp130, which destroys the docking site for SOCS3 that negatively regulates STAT3 activation, develop antral gastric cancer $[19,20,49]$. In addition, in the present study we observed that $H$. pylori-positive individuals harbouring AG or GG genotypes had high degree of mononuclear cells in the gastric corpus, considered a pre malignant lesion.

Although to date, no functional role has been attributed to STAT3 rs744166 polymorphism, in this study, the expression of STAT3 mRNA was significantly higher in stimulated PBMCs from a group of healthy volunteers, carrying the GG genotype, than from those carrying AG or AA genotype. Supporting these findings we also found that the phosphorylated protein STAT3 expression was significantly higher in the gastric tissue of patients carrying the GG genotype than in those carrying AG or GG genotype. Based on these findings, we might suppose that STAT3 rs744166 polymorphism is functional, or is in Hardy-Weinberg disequilibrium with other polymorphism that increases STAT3 transcription and STAT3 secretion.

Of note, in this study we observed differences in the risk of gastric cancer according to the gender; when gastric cancer patients were compared with blood donors, the $\mathrm{G}$ allele being associated with increased risk of gastric cancer only in males. Otherwise, although infection with higher number of EPIYA-C segments was associated with pre malignant lesions (data not shown) and gastric cancer in both males and females, we found that the odds ratio of having gastric cancer was more robust in females (3.49 vs. 2.69). Based on these findings, one may speculate that there are different pathways of 

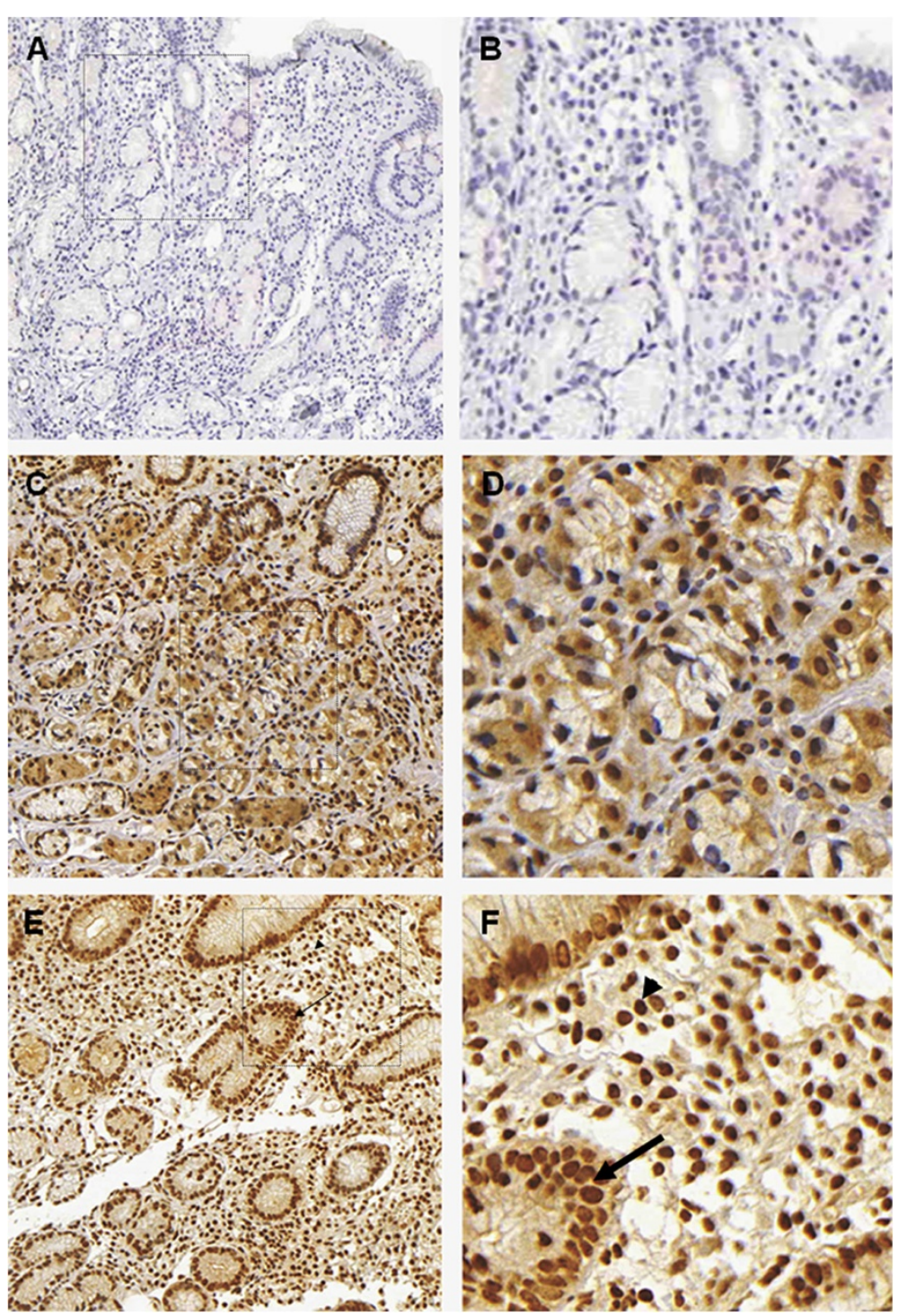

Fig. 2 Representative immunohistochemical staining showing nuclear localization of p-STAT3 in the antral glandular cells and stroma cells under low-power (100x) and high-power (400x) magnification of carriers of AA and GG STAT3 rs744166 genotypes: $\mathbf{a}$ and $\mathbf{b}$, mock; c and $\mathbf{d}$, medium brown-colored nuclei in the gastric stroma cells and glandular cells of a carrier of AA genotype and $\mathbf{e}$ and $\mathbf{f}$, densely stained nuclei of $100 \%$ of cells, both of the gastric stroma (arrow head) and glands (arrow) in a carrier of GG genotype. The percentage of positive cells for STAT3 was classified as 0 (none), 1 ( $\leq 50 \%), 2$ (50 to $90 \%)$, and 3 (> $90 \%$ ) and staining intensity was graded in three step scale, as follows: 1 (low), 2 (medium) and 3 (high) intensity

carcinogenesis between males and females. EPIYA-C binds to one or two SH2 domains of SHP-2, which in turn potentiates Ras-ERK signalling pathway that results in oncogenic stress [50], meanwhile, STAT3 polymorphism possibly activates JAK/STAT3 pathway. However, we can not rule out that the differences observed might be due to a bias because the number of females is smaller than that of males in the blood donors.

When we compared gastritis and gastric cancer patients, we also demonstrated that the association was more robust in the presence of concurrent STAT3 polymorphism and the infection with CagA strains with higher number of EPIYA-C segments, highlighting the relevance of both bacterial and host factors as predictors of gastric cancer. Remarkably we found that in patients with gastric cancer the rs744166 GG genotype and infection with CagA strains with higher number EPIYA-C segments predominate.

\section{Conclusions}

In conclusion, the present study shows that STAT3 rs744166 polymorphism and infection with $H$. pylori with CagA possessing higher number of EPIYA-C segments are independent risk factors for gastric cancer in 

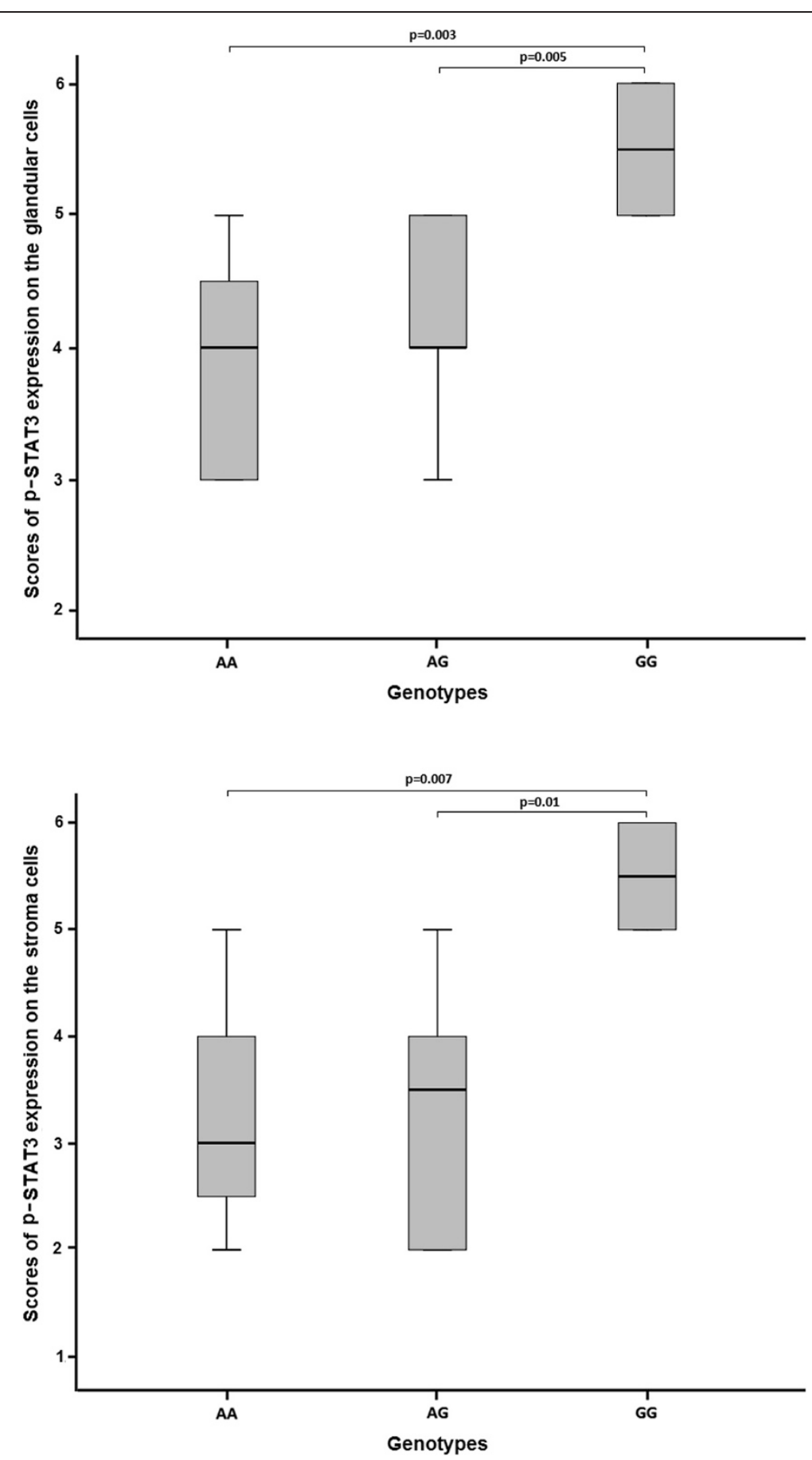

Fig. 3 Box plots representing scores of nuclear P-STAT3 expression in the antral glandular cells and stroma cells of patients with gastritis according to the different STAT3 rs744166 gentotypes. The upper and lower limits of the boxes represent the 75th and 25th percentiles, respectively; the horizontal bar across the box indicates the median and the end of the vertical lines indicate the minimum and maximum data values

the evaluated population. Therefore, individuals with genetic polymorphisms associated to STAT3 who are colonized by CagA strains with higher number of EPIYA-C segments are most likely to benefit from $H$. pylori eradication aiming to prevent gastric cancer as it has been recommended by the IARC working group on
Helicobacter pylori eradication as a strategy for preventing gastric cancer. According to the group all countries should explore the possibility of introducing populationbased $H$. pylori screening and treatment programmes especially for subpopulations that appear most likely to benefit from interventions. 


\section{Competing interests}

The authors declare that they have no competing interests.

\section{Authors' contributions}

FFM, VCF, NBFA, KSB Performed DNA extraction and evaluated STAT3 polymorphism; KSB, SAB, stimulated PBMC and extracted RNA, ADG and CLLFJr and SAB obtained CDNA and performed qRT-PCR. DDMQ designed the study, supervised the laboratory work and analyzed the data. GAR obtained grants. DMMQ, GAR and AMCR wrote the paper. All authors read and approved the manuscript.

\section{Acknowledgements}

We are grateful to Professors Lucia Porto by helping in the immunohistochemistry and Paula Vieira Teixeira Vidigal for documentation of the immunohistochemistry.

This work was supported by grants from the CAPES (Coordenação de Aperfeiçoamento de Nível Superior), CNPq (Conselho Nacional de Ciência e Tecnologia), FAPEMIG (Fundação de Amparo à Pesquisa do Estado de Minas Gerais) and INCT (Instituto Nacional de Ciências e Tecnologia), Brazil.

Received: 5 March 2015 Accepted: 2 July 2015

Published online: 19 July 2015

\section{References}

1. IARC Helicobacter pylori Working Group. Helicobacter pylori Eradication as a Strategyfor Preventing Gastric Cancer. Lyon, France: International Agency for Research on Cancer (IARC Working Group Reports, No. 8); 2014. Available from: http://www.iarc.fr/en/publications/pdfs-online/wrk/wrk8/index.php.

2. El-Omar EM, Carrington M, Chow WH, McColl KE, Bream JH, Young HA, et al. Interleukin-1 polymorphisms associated with increased risk of gastric cancer. Nature. 2000;404:398-402.

3. Figueiredo C, Machado JC, Pharoah P, Seruca R, Sousa S, Carvalho R, et al. Helicobacter pylori and interleukin 1 genotyping: an opportunity to identify high-risk individuals for gastric carcinoma. J Natl Cancer Inst. 2002;94:680-7.

4. El-Omar EM, Rabkin CS, Gammon MD, Vaughan TL, Risch HA, Schoenberg $\mathrm{JB}$, et al. Increased risk of noncardia gastric cancer associated with proinflammatory cytokine gene polymorphisms. Gastroenterology. 2003;124:1193-201.

5. Machado JC, Figueiredo C, Canedo P, Pharoah P, Carvalho R, Nabais S, et al. A proinflammatory genetic profile increases the risk for chronic atrophic gastritis and gastric carcinoma. Gastroenterology. 2003;125:364-71.

6. Rocha GA, Guerra JB, Rocha AM, Saraiva IE, da Silva DA, de Oliveira CA, et al. ILIRN polymorphic gene and cagA-positive status independently increase the risk of noncardia gastric carcinoma. Int J Cancer. 2005;115:678-83.

7. Yu H, Pardoll D, Jove R. STATs in cancer inflammation and immunity: a leading role for STAT3. Nat Rev Cancer. 2009;9:798-809.

8. Bromberg JF, Wrzeszczynska MH, Devgan G, Zhao Y, Pestell RG, Albanese C, et al. STAT3 as an oncogene. Cell. 1999;98:295-303.

9. Benekli M, Xia Z, Donohue KA, Ford LA, Pixley LA, Baer MR, et al. Constitutive activity of signal transducer and activator of transcription 3 protein in acute myeloid leukemia blasts is associated with short disease-free survival. Blood. 2002;99:252-7.

10. Masuda M, Toh S, Koike K, Kuratomi Y, Suzui M, Deguchi A, et al. The roles of JNK1 and Stat3 in the response of head and neck cancer cell lines to combined treatment with all-trans-retinoic acid and 5-fluorouracil. Jpn J Cancer Res. 2002;93:329-39.

11. Sansone P, Storci G, Tavolari S, Guarnieri T, Giovannini C, Taffurelli M, et al. IL-6 triggers malignant features in mammospheres from human ductal breast carcinoma and normal mammary gland. J Clin Invest. 2007;117: 3988-4002.

12. Grivennikov S, Karin E, Terzic J, Mucida D, Yu GY, Vallabhapurapu S, et al. IL-6 and Stat3 are required for survival of intestinal epithelial cells and development of colitis-associated cancer. Cancer Cell. 2009;5:103-13.

13. He G, Karin M. NF-KB and STAT3- key players in liver inflammation and cancer. Cell Res. 2011;1:159-68. doi:10.1038/cr.2010.183.

14. Shin J, Lee HJ, Jung DB, Jung JH, Lee HJ, Lee EO, et al. Suppression of STAT3 and HIF-1 alpha mediates anti-angiogenic activity of betulinic acid in hypoxic PC-3 prostate cancer cells. PLoS One. 2011;6:e21492.

15. Ernst M, Putoczki TL. Stat3: linking inflammation to (gastrointestinal) tumourigenesis. Clin Exp Pharmacol Physiol. 2012;39:711-8.
16. Fukada T, Hibi M, Yamanaka Y, akahashi-Tezuka M, Fujitani Y, Yamaguchi T, et al. Two signals are necessary for cell proliferation induced by a cytokine receptor gp130: involvement of STAT3 in anti-apoptosis. Immunity. 1996:5:449-60

17. Zhang W, Chan RJ, Chen H, Yang Z, He Y, Zhang X, et al. Negative regulation of Stat3 by activating PTPN11 mutants contributes to the pathogenesis of Noonan Syndrome and juvenile myelomonocytic leukemia. J Biol Chem. 2009;284:22353-63.

18. Blechacz BR, Smoot RL, Bronk SF, Werneburg NW, Sirica AE, Gores GJ. Sorafenib inhibits signal transducer and activator of transcription-3 signaling in cholangiocarcinoma cells by activating the phosphatase shatterproof 2 . Hepatology. 2009;50:1861-70.

19. Tebbutt NC, Giraud AS, Inglese M, Jenkins B, Waring P, Clay FJ, et al. Reciprocal regulation of gastrointestinal homeostasis by SHP2 and STAT-mediated trefoil gene activation in gp130 mutant mice. Nat Med. 2002;8:1089-97.

20. Judd LM, Aldermna BM, Howelet M, Shulkes A, Dow C, Moverley J, et al. Gastric cancer development in mice lacking SHP-2 binding site on the IL-6 family co-receptor gp130. Gastroenterology. 2004;126:196-207.

21. Yuan K, Liu H, Huang L, Ren X, Liu J, Dong X, et al. rs744166 polymorphism of the STAT3 gene is associated with risk of gastric cancer in a Chinese population. Biomed Res Int. 2014;2014:527918.

22. Ryan BM, Wolff RK, Valeri N, Khan M, Robinson D, Paone A, et al. An analysis of genetic factors related to risk of inflammatory bowel disease and colon cancer. Cancer Epidemiol. 2014;38:583-90.

23. Jiang B, Zhu ZZ, Liu F, Yang $L$, Zhang WY, Yuan HH, et al. STAT3 gene polymorphisms and susceptibility to non-small cell lung cancer. Genet Mol Res. 2011;10:1856-65.

24. Kwon EM, Salinas CA, Kolb S, Fu R, Feng Z, Stanford JL, et al. Genetic polymorphisms in inflammation pathway genes and prostate cancer risk. Cancer Epidemiol Biomarkers Prev. 2011;20:923-33.

25. Xie J, Zhang Y, Zhang Q, Han Y, Yin J, Pu R, et al. Interaction of signal transducer and activator of transcription 3 polymorphisms with hepatitis $B$ virus mutations in hepatocellular carcinoma. Hepatology. 2013;57:2369-77.

26. Zhang J, Wu J, Peng X, Song J, Wang J, Dong W. Associations between STAT3 rs744166 Polymorphisms and Susceptibility to Ulcerative Colitis and Crohn's Disease: A Meta-Analysis. PLoS One. 2014;9:e109625.

27. Blaser MJ, Perez-Perez Gl, Kleanthous H, Cover TL, Peek RM, Chyou PH, et al. Infection with Helicobacter pylori strains possessing cagA is associated with an increased risk of developing adenocarcinoma of the stomach. Cancer Res. 1995;55:2111-5.

28. Basso D, Zambon CF, Letley DP, Stranges A, Marchet A, Rhead JL. Clinical relevance of Helicobacter pylori cagA and vacA gene polymorphisms. Gastroenterology. 2008;135:91-9.

29. Naito M, Yamazaki T, Tsutsumi R, Higashi H, Onoe K, Yamazaki S, et al. Influence of EPIYA-repeat polymorphism on the phosphorylationdependent biological activity of Helicobacter pylori CagA. Gastroenterology. 2006;130:1181-90.

30. Batista SA, Rocha GA, Rocha AM, Saraiva IE, Cabral MM, Oliveira RC. Higher number of Helicobacter pylori CagA EPIYA C phosphorylation sites increases the risk of gastric cancer, but not duodenal ulcer. BMC Microbiol. 2011;11:e61.

31. Hatakeyama M. Oncogenic mechanisms of the Helicobacter pylori CagA protein. Nat Rev Cancer. 2004;4:688-94.

32. Parra FC, Amado RC, Lambertucci JR, Rocha J, Antunes CM, Pena SD. Color and genomic ancestry in Brazilian. Proc Natl Acad Sci US. 2003;100:177-82.

33. Dixon MF, Genta RM, Yardley JH, Correa P. Classification and grading of gastritis. The updated Sydney System. International Workshop on the Histopathology of Gastritis, Houston 1994. Am J Surg Pathol. 1996;20: 1161-81.

34. Clayton CL, Kleanthous H, Coates PJ, Morgan DD, Tabaqchali S. Sensitive Detection of Helicobacter-pylori by Using Polymerase Chain-Reaction. J Clin Microbiol. 1992;30:192-200.

35. Kelly SM, Pitcher MC, Farmery SM, Gibson GR. Isolation of Helicobacter pylori from feces of patients with dyspepsia in the United Kingdom. Gastroenterology. 1994;107:1671-4.

36. Peek Jr RM, Miller GG, Tham KT, Perez-Perez Gl, Cover TL, Atherton JC, et al Detection of Helicobacter pylorigene expression in human gastric mucosa. J Clin Microbiol. 1995;33:28-32.

37. Yamaoka Y, El-Zimaity HMT, Gutierrez O, Figura N, Kim JK, Kodama T, et al. Relationship between the cagA 3 ' repeat region of Helicobacter pylori, 
gastric histology, and susceptibility to low pH. Gastroenterology. 1999;117:342-9.

38. Rocha GA, Oliveira AM, Queiroz DM, Mendes EN, Moura SB, Oliveira CA, et al. Serodiagnosis of Helicobacter pylori infection by Cobas Core ELISA in adults from Minas Gerais, Brazil. Braz J Med Biol Res. 1998;31:1263-8.

39. Rocha AM, Rocha GA, Santos A, de Oliveira CA, Queiroz DM. Accuracy of a commercial enzyme-linked immunosorbent assay for CagA in patients from Brazil with and without gastric carcinoma. J Clin Microbiol. 2003:41:447-8.

40. Livak K, Schmittgen TD. Analysis of relative gene expression data using real-time quantitative PCR and the 2(-Delta Delta C(T)). Method Methods. 2001:4:402-8.

41. Kim DY, Cha ST, Ahn DH, Kang HY, Kwon Cl, Ko KH, et al. STAT3 expression in gastric cancer indicates a poor prognosis. J Gastroenterol Hepatol. 2009;24:646-51.

42. Woo S, Lee BL, Yoon J, Cho SJ, Baik TK, Chang MS, et al. Constitutive activation of signal transducers and activators of transcription 3 correlates with better prognosis, cell proliferation and hypoxia-inducible factor-1a in human gastric cancer. Pathobiology. 2011;78:295-301.

43. Hosmer DW, Lemeshow S. Applied Logistic Regression, JH. New York: Wiley Interscience Publication; 2000.

44. Camargo MC, Mera R, Correa P, Peek Jr RM, Fontham ET, Goodman K, et al. Interleukin-1 beta and interleukin-1 receptor antagonist gene polymorphisms and gastric cancer: a meta-analysis. Cancer Epidemiol Biomarkers Prev. 2006;15:1674-87.

45. Hruz P, Dann SM, Eckmann L. STAT3 and its activators in intestinal defense and mucosal homeostasis. Curr Opin Gastroenterol. 2010;26:109-15.

46. Jackson CB, Giraud AS. STAT3 as a prognostic marker in human gastric cancer. J Gastroenterol Hepatol. 2009:4:505-7.

47. Wilson TA, Jurickova I, Collins M, Denson LA. Deletion of intestinal epithelial cell STAT3 promotes T-lymphocyte STAT3 activation and chronic colitis in mice. Inflamm Bowel Dis. 2013;19:512-25.

48. Park WS, Oh RR, Park JY, Lee JH, Shin MS, Kim HS, et al. Somatic mutations of the trefoil factor family 1 gene in gastric cancer. Gastroenterology. 2000;119:691-8.

49. Jenkins BJ, Grail D, Nheu T, Najdovska M, Wang B, Waring P, et al. Hyperactivation of Stat3 in gp130 mutant mice promotes gastric hyperproliferation and desensitizes TGF-beta signaling. Nat Med. 2005;11:845-52.

50. Saito Y, Murata-Kamiya N, Hirayama T, Ohba Y, Hatakeyama M. Conversion of Helicobacter pyloriCagA from senescence inducer to oncogenic driver through polarity-dependent regulation of p21. J Exp Med. 2010;207: 2157-74.

\section{Submit your next manuscript to BioMed Central and take full advantage of:}

- Convenient online submission

- Thorough peer review

- No space constraints or color figure charges

- Immediate publication on acceptance

- Inclusion in PubMed, CAS, Scopus and Google Scholar

- Research which is freely available for redistribution 